additional material such as pericardium or homografts. It has been demonstrated to be effective in our early experience.

\section{References}

1. Health manpower requirements for the achievement of health for all by the year 2000 through primary health care. Report of a WHO Expert Committee. World Health Organ Tech Rep Ser. 1985;717:7-92.

2. Saxena A. Congenital heart disease in India. A status report. Ind J Pediatr. 2005;72:595-8.
3. Novick WM, Sandoval N, Lazorhysynets VV, Castillo V, Baskevitch A, Mo X, et al. Flap valve double patch closure of ventricular septal defects in children with increased pulmonary vascular resistance. Ann Thorac Surg. 2005;79:21-8.

4. Zhou Q, Lai $Y$, Wei H, Song R, Wu Y, Zhang H. Uidirectional valve patch for repair of cardiac septal defects with pulmonary hypertension. Ann Thorac Surg. 1995;60:1245-9.

5. Zhang B, Wu S, Liang J, Zhang G, Jiang G, Zhou M, et al. Unidirectional monovalve homologous aortic patch for repair of ventricular septal defect with pulmonary hypertension. Ann Thorac Surg. 2007;83: 2176-81

\title{
The axillary incision: A cosmetic approach in congenital cardiac surgery
}

Khanh Nguyen, MD, ${ }^{\text {a }}$ Cynthia Chin, MD, ${ }^{a}$ Dong-Seok Lee, MD, ${ }^{a}$ Alexander Mittnacht, MD, ${ }^{\text {b }}$ Shubikha Srivastava, MD, Joashi Umesh, MD, ${ }^{c}$ Steven Walker, RN, ${ }^{d}$ and David Adams, MD, ${ }^{a}$ New York, NY, and Paterson, NJ

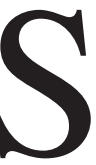

urgery for congenital heart disease has made great advances, and the focus has shifted from simply surviving the operation to the quality of life after surgical repair, especially when dealing with simple lesions such as atrial septal defects (ASDs). In children and young women, the appearance of the incision has been a significant issue, with concern that it could have an impact on the patient's psychological wellbeing and self esteem.

Several approaches have been described to avoid a visible midline scar. Most commonly, surgeons have tried using the anterolateral thoracotomy approach, originally described by Lewis and Taufic ${ }^{1}$ in 1952. In addition, there have been reports concerning the use of other access sites such as a short right lateral thoracotomy, posterolateral thoracotomy, ministernotomy, a subxiphoid approach without sternotomy, and, more recently, an axillary incision. ${ }^{2,3}$ The axillary incision scar is well concealed under the upper arm (Figure 1) and, in prepubescent female patients, poses less potential for subsequent breast tissue distortion. ${ }^{4}$ This article reports the use of the axillary incision at our institution in 34 patients with various congenital cardiac defects.

\section{Patients and Methods}

Thirty-four consecutive patients were included in the report. Median age was 5 years, with a range from 5 months to 47 years.

From the Departments of Cardiothoracic Surgery, ${ }^{\mathrm{a}}$ Anesthesiology, ${ }^{\mathrm{b}}$ and Pediatrics, ${ }^{\mathrm{c}}$ Mount Sinai Medical Center, New York, NY; and the Division of Pediatric Cardiology, ${ }^{\text {d }}$ St Joseph's Medical Center, Paterson, NJ.

Received for publication June 8, 2007; accepted for publication June 21, 2007.

Address for reprints: Khanh H. Nguyen, MD, Mount Sinai Medical Center, Department of Cardiothoracic Surgery, 1190 Fifth Ave, Box 1028, New York, NY 10029 (E-mail: Khanh.Nguyen@mountsinai.org).

J Thorac Cardiovasc Surg 2007;134:1358-60

$0022-5223 / \$ 32.00$

Copyright $\odot 2007$ by The American Association for Thoracic Surgery doi:10.1016/j.jtcvs.2007.06.033
Median weight was $21 \mathrm{~kg}$, with a range from 5.9 to $72 \mathrm{~kg}$. Clinical and operative data regarding the 34 patients are shown in Table 1.

We opted to evaluate the axillary incision against the commonly used incision, the ministernotomy. A subgroup of patients with secundum ASDs was compared with 14 other recent patients who had a secundum ASD closure through a ministernotomy incision. Their clinical data and the results of statistical analysis of this comparison are shown in Table 2.

Data gathering adhered to Mount Sinai and St Joseph's Medical Center Institutional Review Board guidelines. The protocol was approved by the Institutional Review Board, and specific patient consent was not required.

\section{Surgical Techniques}

Ministernotomy. The technique has been well described. ${ }^{5} \mathrm{~A}$ majority of patients had repair with the heart electrically fibrillated, and the defects were closed primarily. For larger lesions, the defects were closed with an autologous pericardial patch.

Right axillary incision. The patient was placed in the left lateral decubitus position. The right arm was elevated to expose the axilla. The slightly oblique incision was placed between the anterior and posterior axillary lines.

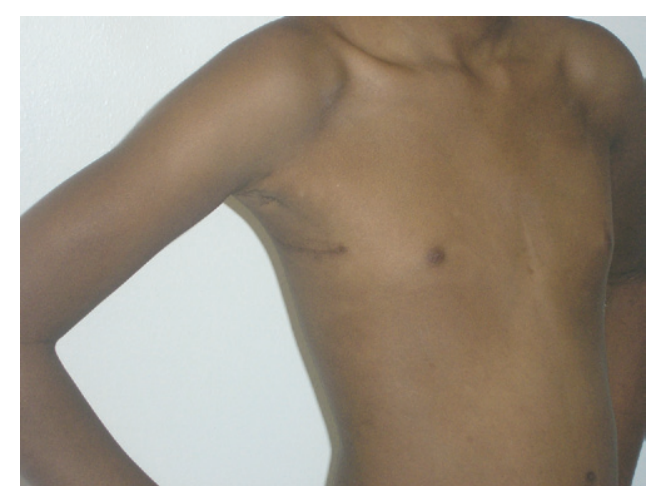

Figure 1. The scar for the axillary incision is positioned under the upper arm. 
TABLE 1. Clinical and operative data

\begin{tabular}{|c|c|c|c|c|c|c|c|}
\hline Diagnosis & No. & Female & Age (mo) & Weight (kg) & CBP (min) & Crossclamp (min) & Fibrillation (min) \\
\hline Secundum ASD & 16 & 12 & $77(11,572)$ & $21(7,72)$ & $29(51-9)$ & $16(9,25)$ in 7 patients & $9(4,16)$ in 9 patients \\
\hline $\begin{array}{l}\text { Sinus venosus ASD, superior } \\
\text { type PAPVR }\end{array}$ & 6 & 2 & $52(14,145)$ & $15(8,55)$ & $71(50,90)$ & $43(27,53)$ & \\
\hline $\begin{array}{l}\text { Sinus venosus ASD, inferior } \\
\text { type, PAPVR }\end{array}$ & 3 & 1 & $135(118,220)$ & $37(27,58)$ & $65(30,84)$ & $33(16,66)$ & \\
\hline Perimembranous VSD & 4 & 2 & $17(6,23)$ & $8(6-10)$ & $126(108,129)$ & $73(48,105)$ & \\
\hline Inlet VSD & 1 & 1 & 5 & 6 & 128 & 85 & \\
\hline Sub AS & 3 & 2 & $65(58,95)$ & $27(20,31)$ & $72(50,78)$ & $42(26,52)$ & \\
\hline TV regurgitation & 1 & 1 & 38 & 20 & 233 & 184 & \\
\hline
\end{tabular}

$A S D$, Atrial septal defect; PAPVR, partial anomalous pulmonary venous return; VSD, ventricular septal defect; Sub $A S$, subaortic stenosis; $T V$, tricuspid valve.

The incisions usually measured about 1.5 inches in a $10-\mathrm{kg}$ infant to almost 3 inches in adults. The serratus anterior muscle was split along its fibers and the latissimus dorsi was retracted posteriorly. The pleural cavity was entered through the fourth intercostal space. Aortic and bicaval cannulations were then achieved, and cardiopulmonary bypass (CPB) was instituted. The conduct of the operation is similar to that of ministernotomy.

\section{Statistical Methods}

Data are described as percentages or median and range, as appropriate. Comparisons of categorical factors between the 2 procedures are by exact $\pi^{2}$ tests. Wilcoxon tests were used to compare continuous measures. Data analyses were implemented with SAS software, version 9.1 (SAS Institute Inc, Cary, NC).

\section{Results}

There was 1 case of transient and 1 case of permanent atrioventricular block. One patient, who had first-degree heart block preoperatively, required a permanent pacemaker placed after closure of a ventricular septal defect. All but 1 patient were extubated in the operating room. Intraoperative and follow-up echocardiograms showed no residual lesions in any patient.

TABLE 2. Comparison of patients undergoing axillary incision and those undergoing ministernotomy

\begin{tabular}{|c|c|c|c|}
\hline $\begin{array}{l}\text { Variables (median } \\
\text { values) }\end{array}$ & $\begin{array}{l}\text { Axillary } \\
(n=16)\end{array}$ & $\begin{array}{l}\text { Ministernotomy } \\
\quad(\mathrm{n}=14)\end{array}$ & $P$ values \\
\hline Age (mo) & $77(11,572)$ & $59(14,191)$ & .79 \\
\hline Weight (kg) & $21.0(6.8,72.0)$ & $19(8,53)$ & .72 \\
\hline $\begin{array}{l}\text { Time before CPB } \\
(\min )^{*}\end{array}$ & $65(44,126)$ & $47(35,98)$ & .06 \\
\hline CPB (min) & $29(9,51)$ & $11(8,54)$ & .0012 \\
\hline $\begin{array}{l}\text { Crossclamp time } \\
\text { (min) }\end{array}$ & $\begin{array}{c}16(9,23) \text { (in } 7 \\
\text { patients) }\end{array}$ & 26 in 1 patient & .25 \\
\hline $\begin{array}{l}\text { Fibrillation time } \\
\text { (min) }\end{array}$ & $\begin{array}{c}10(4,16) \text { in } 9 \\
\text { patients }\end{array}$ & $\begin{array}{c}5(3,10) \text { in } 13 \\
\text { patients }\end{array}$ & .003 \\
\hline Surgery time $(\min ) \dagger$ & $137(105,221)$ & $99(76,175)$ & .01 \\
\hline $\operatorname{LOS}(\mathrm{d})$ & $2.0(1.0,4.0)$ & $1.0(1.0,3.0)$ & .07 \\
\hline
\end{tabular}

$C P B$, Cardiopulmonary bypass; $L O S$, length of stay. ${ }^{*}$ Time from skin incision to initiation of $\mathrm{CPB}$. †Time from skin incision to skin closure.
Intraoperative data from the patients who had an axillary incision are shown in Table 1. Data and statistical analysis on the 2 groups of patients with secundum ASDs are shown in Table 2. As can be seen from the table, the CPB times and the overall duration of surgery were significantly greater for the patients with axillary incisions.

\section{Discussion}

The axillary incision has been commonly used for thoracic operations. Our goal to achieve a cosmetic result in surgery for congenital cardiac lesions had led us to the application of the axillary incision. Our experience showed that repair of certain congenital defects through an axillary incision using central cannulation is possible. Lesions at the atrial level, lesions close to the tricuspid valve, and those that can be visualized and reached from the unique angle dictated by the axillary incision seem amenable to the axillary approach. The smallest patient was $5.9 \mathrm{~kg}$.

When compared with patients with ASD closed via a ministernotomy, there is clearly an increase in $\mathrm{CPB}$ and fibrillation times in patients with axillary incision, but the two groups had no differences in postoperative outcomes or length of stay. Because it was a new approach, there was a tendency to use a more complete open heart setup with mild hypothermia and crossclamping in the axillary incision group, as our data noted. Up to $44 \%$ of patients in the axillary group had aortic crossclamping, in contrast to $7 \%$ in the ministernotomy group, contributing to a longer duration of $\mathrm{CPB}$. In fact, when only normothermia and fibrillation were used in patients with an axillary incision, the CPB and fibrillation times approached those of patients with the ministernotomy approach.

The study sample was small, but it did provide useful data when compared with that of the more commonly performed ministernotomy. The axillary incision is not suitable for many complex congenital cardiac lesions and the sternotomy is still the standard and most effective approach.

In conclusion, the axillary incision provides a superior cosmetic result in repairing a variety of congenital cardiac lesions. We anticipate its wider application in patients with mitral and aortic valve disease, as well as in surgery of the ascending aorta.

\section{References}

1. Lewis FJ, Taufic M. Closure of atrial septal defects with the aid of hypothermia: experimental accomplishments and report of one successful case. Surgery. 1953;33:52-9. 
2. Pretre R, Kadner A, Dave H, Dodge-Khatami A, Bettex D, Berger F. Right axillary incision: a cosmetically superior approach to repair a wide range of congenital cardiac defects. J Thorac Cardiovasc Surg. 2005;130:277-81.

3. Schreiber C, Bleiziffer S, Kostolny M, Hörer J, Eicken A, Holper K, et al. Minimally invasive midaxillary muscle sparing thoracotomy for atrial septal defect closure in prepubescent patients. Ann Thorac Surg. 2005;80:673-6.
4. Bleiziffer S, Schreiber C, Burgkart R, Regenfelder F, Kostolny M, Libera $\mathrm{P}$, et al. The influence of right anterolateral thoracotomy in prepubescent female patients on late breast development and on the incidence of scoliosis. J Thorac Cardiovasc Surg. 2004;127:1474-80.

5. Nicholson IA, Bichell DP, Bacha EA, del Nido PJ. Minimal sternotomy approach for congenital heart operations. Ann Thorac Surg. 2001;71: $469-72$.

\section{Immediate "total" aortic true lumen expansion in type A and B acute aortic dissection after endovascular aortic endografting and GZSD bare stenting}

Peter Mossop, MB, BS, FRACR, ${ }^{a}$ Ian Nixon, MB, BS, FRACS, ${ }^{b}$ John Oakes, MB, BS, ${ }^{\text {a }}$ Terry J. Devine, MB, BS, FRACS, ${ }^{c}$ and Craig S. McLachlan, PhD, MPH, ${ }^{d}$ Melbourne, Victoria, Australia

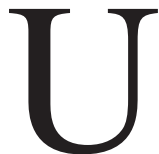
se of bare metal stenting is a novel approach for more complete reconstruction of aortic dissection. ${ }^{1}$ Treatment advancement with endografting ${ }^{2,3}$ and bare stenting for total aortic reconstruction has been previously reported. ${ }^{1}$ In this article we report our results for complete endovascular aortic stenting in acute dissection for both type A and B cases.

From the Vascular Interventional Section, Medical Imaging, ${ }^{a}$ and the Department of Cardiothoracic Surgery, ${ }^{\mathrm{b}}$ St Vincent's Hospital Melbourne; the Department of Vascular Surgery, ${ }^{\mathrm{c}}$ Monash Medical Centre; and the Department of Medicine, ${ }^{\mathrm{d}}$ University of Melbourne, Melbourne, Victoria, Australia.

Peter Mossop, MB, BS, FRACR, and Ian Nixon, MB, BS, FRACS, report consulting fees and royalties from Cook, Inc.

Received for publication Aug 31, 2006; revisions received Feb 20, 2007; accepted for publication March 8, 2007.

Address for reprints: Peter J Mossop, MB, BS, FRACR, Director of Vascular Interventional Radiology, St Vincent's Hospital Melbourne, 41 Victoria Parade, Fitzroy, Victoria 3065 Australia (E-mail: Peter.MOSSOP@ svhm.org.au).

J Thorac Cardiovasc Surg 2007;134:1360-2

$0022-5223 / \$ 32.00$

Copyright $\odot 2007$ by The American Association for Thoracic Surgery

doi:10.1016/j.jtcvs.2007.03.064
Deficiencies have persisted with endografts in the treatment of thoracic dissections. ${ }^{4}$ Stent graft closure of the primary entry tear, typically in the proximal descending aorta, results in decompression of the thoracic false lumen with proximal thrombosis and remodeling. However, this technique does not address the need in some cases to more fully remodel the entire aorta and ensure distal branch vessel perfusion. ${ }^{2,3}$ Furthermore, the presence of complex distal re-entries, often related to branch vessels, prohibits extensive treatment with standard tube endografts.

Case reports of Z-stent use for prevention of malperfusion suggest its utility in aortic dissection. ${ }^{5}$ Additionally, we have found bare metal stenting accelerates true lumen remodeling, reduces false lumen volume, and enhances branch vessel perfusion. Our study evaluates quantitatively the postdissection true lumen expansion as a result of $\mathrm{Z}$ stenting with or without additional endografting of the primary entry tear.

From 2002 to 2005, 9 patients were treated for acute aortic dissection (3 type $\mathrm{A}$ and 6 type $\mathrm{B}$ ) using $\mathrm{Z}$ stenting of the thoracic and abdominal aorta. Patient selection included acute phase false lumen growth $(>0.5 \mathrm{~cm})$, malperfusion or mesenteric branch involvement, and true lumen collapse (which did not expand after proximal endograft placement) (Table 1). Initially Gianturco Z stents and subsequently the purpose built Zenith DISSECTION thoracic endovascular

TABLE 1. Procedural and clinical characteristics/outcomes

\begin{tabular}{|c|c|c|c|c|c|}
\hline $\begin{array}{l}\text { Patient } \\
\text { sex/age (y) }\end{array}$ & Dissection type & Aortic indication for stenting & Proximal endograft & Stent type & $\begin{array}{c}\text { Stent dimensions } \\
(\mathrm{mm})\end{array}$ \\
\hline $\mathrm{M} / 60$ & Acute type B & TLC, high-flow FL & ZTEGA 38-177 & GZS & $1 \times 35-75$ \\
\hline $\mathrm{M} / 51$ & Acute type B & Mesenteric involvement & No endograft & GZS & $3 \times 35-75$ \\
\hline $\mathrm{F} / 54$ & Acute type B & High-flow FL involving renal artery & ZTEG 42-135 & GZS & $3 \times 35-75$ \\
\hline $\mathrm{F} / 48$ & Acute type B & TLC & ZTEG 30-120 & GZS & $3 \times 35-75$ \\
\hline $\mathrm{F} / 48$ & Acute type B & TLC & ZTEG 30-120 & GZSD & $46-123,46-82$ \\
\hline $\mathrm{M} / 79$ & Postop type A repair & Mesenteric involvement & No endograft & GZSD & $46-164$ \\
\hline $\mathrm{M} / 50$ & Acute type B & Aorta-infrarenal malperfusion & ZTEG 34-127 & GZSD & $46-164,46-123$ \\
\hline $\mathrm{M} / 57$ & Acute type B & Renal malperfusion & ZTEG 34-127 & GZSD & $46-164,46-123$ \\
\hline $\mathrm{M} / 52$ & Postop type A repair & Postop type A repair & ZTEG 30-120 & GZSD & $46-164,46-82$ \\
\hline
\end{tabular}

$F L$, False lumen; $T L$, true lumen; $S G$, stent graft; $T L C$, symptomatic true lumen collapse; $T$, total; $P$, partial; $N$, no; $Y$, yes. 